\title{
Renal cell cancer: what can we learn from pre-operative studies?
}

\section{Rosalie Fisher and James Larkin* \\ Department of Medical Oncology, Royal Marsden Hospital, London, UK \\ *Correspondence: james.larkin@rmh.nhs.uk}

Renal cell carcinoma (RCC) affects approximately 60,000 people in Europe and in the United States each year (Ferlay et al., 2007; Jemal et al., 2010), and is associated with high rates of morbidity and mortality. The incidence of RCC is rising, perhaps because of the widespread use of abdominal imaging, resulting in an increased detection of small renal masses, and surgical intervention for these (Hollingsworth et al., 2006; Falebita et al., 2009). Surgery remains an integral part of the management of RCC, and is the only curative treatment in patients with disease confined to the kidney and its regional vasculature and lymph nodes. However, about $30 \%$ of patients are diagnosed with metastatic renal cell carcinoma (mRCC) at presentation (Motzer et al., 1996) and a similar proportion will later develop metastases (Leibovich et al., 2003). Until 2007, a combination of cytoreductive nephrectomy $(\mathrm{CN})$ and immunotherapy, usually interferon- $\alpha$, was considered to be the standard of care for those patients presenting with mRCC deemed fit enough, although cytokine therapy was associated with modest benefits and much toxicity (Coppin et al., 2005). The basis for nephrectomy in the context of metastatic disease was provided by two similar prospective trials which randomized patients to $\mathrm{CN}$ plus interferon or interferon alone. Combined analysis of the two trials demonstrated a median survival of 13.6 months for surgery plus interferon, and 7.8 months for interferon alone $(\mathrm{HR}=0.69$, $95 \% \mathrm{CI}=0.55-0.87, p=0.002$; Flanigan et al., 2004). The simplest rationale for why $\mathrm{CN}$ might improve survival in mRCC is a reduction in overall tumor burden, thus delaying time to a lethal burden of disease; other theories include a decrease in the amount of tumor shedding and systemic signaling from the primary renal mass, effective palliation of pain, bleeding and paraneoplastic syndromes, and removal of a source of significant immunosuppression. The latter was proposed on the basis of reports of spontaneous regression in
mRCC, which occurs very rarely, but this phenomenon was also observed in series when surgery was not performed (Russo and O'Brien, 2008). Despite the evidence for a combined modality approach to $\mathrm{mRCC}$ in the cytokine era, these agents did not improve clinical outcomes when studied in the adjuvant setting (Pizzocaro et al., 2001; Messing et al., 2003; Atzpodien et al., 2005), and were not tested as neoadjuvant treatment due to their side effects and the very limited response rates observed in the primary tumors.

Since that time, a number of new, biological therapies for mRCC have emerged, resulting in marked improvements in clinical outcomes in this disease. The multi-targeted tyroskine kinase inhibitors (TKIs), which include sunitinib, sorafenib, and pazopanib, have all demonstrated significant gains in median progression-free survival times in phase III trials, and probably improve overall survival as well (Escudier et al., 2007a; Motzer et al., 2007; Sternberg et al., 2010a,b). Temsirolimus and everolimus are mammalian target of rapamycin (mTOR) inhibitors and were also established as effective therapies for patients with poor-prognosis, untreated mRCC and for second line therapy after TKIs respectively (Hudes et al., 2007; Motzer et al., 2008b). Bevacizumab, a humanized monoclonal antibody against vascular endothelial growth factor (VEGF) improved progression-free survival when combined with interferon, compared to interferon alone in two phase III trials (Escudier et al., 2007b; Rini et al., 2008). The lack of overall survival benefit reported in many of these trials could be explained by the fact that the majority of subjects received subsequent anti-angiogenic treatments. However, it is well recognized that, despite these advances, treatment for most patients remains non-curative, and that these therapies have serious limitations. A lack of systematic tissue collection in the phase III trials of these agents means there is inadequate understanding of the biological mechanisms underlying response and resistance to treatment, and there are no established predictive biomarkers, and no basis for selection of therapy for an individual patient. Successful treatment of mRCC is based on knowledge of critical molecular signaling pathways, but clinicopathological models such as the MSKCC scoring system, developed to categorize patients treated with cytokines into favorable, intermediate and poor risk prognosis groups (Motzer et al., 2002), are still applied to patients treated in the kinase inhibitor era. Although newer tools have been developed for use in patients treated with anti-angiogenic therapies (Motzer et al., 2008a; Heng et al., 2009), these are largely based on traditional markers of risk, rather than molecular characteristics and so there remains scope for refinement.

One approach therefore is to look toward pre-operative studies to inform us of the optimal treatment of RCC, whether it is early or advanced stage. Pre-operative treatment is a broad term which is often interchanged with, and includes, neoadjuvant treatment; the latter specifically applies to patients treated with curative intent, but in who there is locally advanced, and often inoperable tumor, at the outset. Neoadjuvant therapy is increasingly used in many tumor types for the following reasons: it can downsize a bulky tumor thus enabling safer and more effective surgery, there is early treatment of micrometastatic disease, it provides an in vivo test of systemic treatment response, and importantly, it provides tissue which is critical for research into surrogate markers of biological processes. A neoadjuvant approach may be particularly relevant to RCC, in which the primary tumors tend to grow slowly, reducing the risk of significant disease progression while surgery is awaited, and because clinical experience of the newly available systemic therapies indicates that tumor shrinkage occurs early after treatment initiation and is often followed by a prolonged period of disease stability. 
Furthermore, rates of objective response in the primary tumor appear to be higher with drugs such as sunitinib than was observed with cytokine therapy (Shuch et al., 2008; van der Veldt et al., 2008). Pre-operative, rather than neoadjuvant, therapy includes patients with metastatic disease, and as well as defining the role of surgery in patients treated with biological therapies, it may provide answers to the many unmet clinical needs in mRCC described above.

Pre-operative studies in RCC are limited to a small number of retrospective analyses and phase II studies. Retrospective surgical series, each involving small numbers of patients, mainly focused on the safety aspects of peri-operative therapy with anti-angiogenic drug therapy. Thomas et al. (2009b) presented two retrospective reviews; the first of these included 19 patients treated with sunitinib, sorafenib or bevacizumab with interleukin-2 prior to surgical resection, for locally advanced, locally recurrent or metastatic RCC, and reported low morbidity in most patients, consistent with the results from other institutions (Amin et al., 2008; Margulis et al., 2008; Shuch et al., 2008; Chapin et al., 2011). The second paper from the Cleveland Clinic group not only suggested that pre-operative sunitinib was safe, but also hinted that this approach could be used to convert nonoperable into operable tumors (Thomas et al., 2009a). Nineteen patients who were deemed unsuitable for nephrectomy on the basis of locally advanced or metastatic disease were treated with sunitinib; partial responses were observed in $16 \%$, and stable disease in another 37\%, and four patients had sufficient tumor regression (either in the primary or metastatic disease) to facilitate nephrectomy (21\%). The largest retrospective review of pre-surgical systemic therapy was published recently and indicates that early, minor response in the primary tumor (median size of reduction $-36.4 \%$ ) predicts for improved overall survival (Abel et al., 2011).

A prospective, phase II trial of preoperative sunitinib in patients with locally advanced or metastatic RCC enrolled 20 patients, all of who were deemed suitable for nephrectomy (Hellenthal et al., 2010). Seventeen of the 20 patients had some reduction in tumor diameter on CT at 2 months with a mean change in tumor diameter of $-11.8 \%$. Only one patient had a formal partial response as per RECIST, but tumor enhancement as assessed by contrast CT decreased in a significant number of patients (75\%), and this seemed to correlate with histologic necrosis. There did not appear to be any increase in surgical morbidity attributable to sunitinib, and with a short median follow up of 6.5 months, this study assesses pre-operative therapy from a surgical safety, rather than disease control, perspective. Powles et al. (2011) recently reported on two prospective phase II studies of pre-operative sunitinib in 52 patients with mRCC. Overall, the RECIST clinical benefit and nephrectomy rates were high (73 and $71 \%$ respectively), despite a partial response rate of only $6 \%$, and a median reduction in longest tumor diameter of $12 \%$. Reassuringly, no patients became inoperable while on systemic therapy. This led the authors to conclude that sunitinib prior to nephrectomy was an effective way of controlling disease, but also to question whether the endpoint of response rate in this, and other trials, is appropriate.

Similar results were seen in a pre-operative study of sorafenib, although these patients were considered to be suitable surgical candidates up-front (Cowey et al., 2010). Thirty patients (17 with locally advanced, and 13 with metastatic disease) were treated with sorafenib for a median of 33 days prior to nephrectomy. Most patients achieved shrinkage of the primary tumor, although the median degree of reduction was $-9.6 \%$, and therefore, most patients had stable disease by RECIST (93\%). A subset of patients also underwent contrast-enhanced CT assessment and amongst the 17 evaluable patients, 15 had a reduction in intratumoral density. Despite a short interval between cessation of sorafenib and surgery (median of three days), no additional surgical morbidity was observed in this study.

Finally, a phase II feasibility study of presurgical bevacizumab in 50 patients with mRCC suitable for CN found a median progression-free survival time of 11 months, comparable to the results of the up-front sunitinib and temsirolimus trials (Hudes et al., 2007; Motzer et al., 2007; Jonasch et al., 2009). However, concerns were raised about the rates of delayed wound healing related to anti-angiogenic therapy - demonstrated in nine patients at four postoperative weeks, and one patient required re-operation for wound dehiscence - and the potential for disease progression on preoperative therapy which then excludes the patient from nephrectomy. Of course, this is also one of the arguments in favor of preoperative therapy, in that it might prevent poor-prognosis patients who are refractory to medical therapies from undergoing morbid surgery.

Data from phase III trials integrating pre-operative therapy and surgery, like the EORTC SURTIME and French-led CARMENA studies, will hopefully establish whether a pre-operative approach is an effective means of oncologic control in RCC. Nonetheless, these early pre-operative trials are instructive. Firstly, it seems clear that our current method of assessing response to treatment is inadequate in the antiangiogenic therapy era. If the vast majority of patients in the phase II pre-operative trials achieve minor reductions in disease volume, yet have heterogenous clinical outcomes, then standard CT imaging and the RECIST system is not able to distinguish those patients in whom the natural disease course is altered by this treatment. Newer radiology modalities which assess tumor blood flow, such as arterial spin labeling magnetic resonance imaging (MRI) and dynamic contrast-enhanced MRI (DCEMRI), may be more suitable, but require validation (de Bazelaire et al., 2008; Hahn et al., 2008). Secondly, but perhaps more importantly, trial design in pre-operative studies provides an opportunity for muchneeded tissue collection, so far omitted from large clinical trial protocols in RCC. Biopsies of the primary and metastatic sites at important time points such as at baseline, disease response and disease progression are the key to understanding the molecular mechanisms underlying sensitivity and resistance to the newer treatments. Multiple tissue specimens are required, because it is becoming clear that substantial intra- and inter-tumoral genetic heterogeneity exists in RCC (Moch et al., 1998; Dalgliesh et al., 2010). Intratumoral heterogeneity may contribute significantly to drug resistance (Gerlinger and Swanton, 2010; Lee et al., 2011), and may present a challenge to biomarker discovery in RCC.

On this basis, the European Union multi-disciplinary Personalized RNA Interference to Enhance the Delivery of Individualized Cytotoxic and Targeted therapeutics (PREDICT) consortium is 
currently recruiting patients for several preoperative biopsy studies in mRCC (Swanton et al., 2010). The PREDICT trial designs incorporate functional imaging studies and comprehensive analysis of primary and secondary disease sites, using novel methods of personalized tumor-derived small hairpin RNA and high-throughput small interfering RNA screens, with the following aims: identification of predictive and surrogate biomarkers, determination of the mechanisms of resistance and response to VEGFtargeted therapy, and identification of new targets in RCC. It is our opinion that rationally designed pre-operative RCC studies provide a unique opportunity to study drug treatments for this disease in vivo, and that this may impact on future clinical practice in RCC. This approach almost guarantees the acquisition of tissue; however, careful and standardized measures of quality control are necessary to ensure that the tissue collected is suitable for genomic and other analyses.

\section{REFERENCES}

Abel, E. J., Culp, S. H., Tannir, N. M., Tamboli, P., Matin, S. F., and Wood, C. G. (2011). Early primary tumor size reduction is an independent predictor of improved overall survival in metastatic renal cell carcinoma patients treated with sunitinib. Eur. Urol. 60, 1273-1279.

Amin, C., Wallen, E., Pruthi, R. S., Calvo, B. F., Godley, P. A., and Rathmell, W. K. (2008). Preoperative tyrosine kinase inhibition as an adjunct to debulking nephrectomy. Urology 72, 864-868.

Atzpodien, J., Schmitt, E., Gertenbach, U., Fornara, P., Heynemann, H., Maskow, A., Ecke, M., Woltjen, H. H., Jentsch, H., Wieland, W., Wandert, T., and Reitz, M. (2005). Adjuvant treatment with interleukin-2- and interferon-alpha2a-based chemoimmunotherapy in renal cell carcinoma post tumour nephrectomy: results of a prospectively randomised trial of the German Cooperative Renal Carcinoma Chemoimmunotherapy Group (DGCIN). Br. J. Cancer 92, 843-846.

Chapin, B. F., Delacroix, S. E. Jr., Culp, S. H., Gonzalez, G. M., Tannir, N. M., Jonasch, E., Tamboli, P., and Wood, C. G. (2011). Safety of presurgical targeted therapy in the setting of metastatic renal cell carcinoma. Eur. Urol. 60, 964-971.

Coppin, C., Porzsolt, F., Awa, A., Kumpf, J., Coldman, A., and Wilt, T. (2005). Immunotherapy for advanced renal cell cancer. Cochrane Database Syst. Rev. CD001425.

Cowey, C. L., Amin, C., Pruthi, R. S., Wallen, E. M., Nielsen, M. E., Grigson, G., Watkins, C., Nance, K. V., Crane, J., Jalkut, M., Moore, D. T., Kim, W. Y., Godley, P. A., Whang, Y. E., Fielding, J. R., and Rathmell, W. K. (2010). Neoadjuvant clinical trial with sorafenib for patients with stage II or higher renal cell carcinoma. J. Clin. Oncol. 28, 1502-1507.

Dalgliesh, G. L., Furge, K., Greenman, C., Chen, L., Bignell, G., Butler, A., Davies, H., Edkins, S., Hardy,
C., Latimer, C., Teague, J., Andrews, J., Barthorpe, S., Beare, D., Buck, G., Campbell, P. J., Forbes, S., Jia, M., Jones, D., Knott, H., Kok, C. Y., Lau, K. W., Leroy, C., Lin, M. L., McBride, D. J., Maddison, M., Maguire, S., McLay, K., Menzies, A., Mironenko, T., Mulderrig, L., Mudie, L., O’Meara, S., Pleasance, E., Rajasingham, A., Shepherd, R., Smith, R., Stebbings, L., Stephens, P., Tang, G., Tarpey, P. S., Turrell, K., Dykema, K. J., Khoo, S. K., Petillo, D., Wondergem, B., Anema, J., Kahnoski, R. J., Teh, B. T., Stratton, M. R., and Futreal, P. A. (2010). Systematic sequencing of renal carcinoma reveals inactivation of histone modifying genes. Nature 463, 360-363.

de Bazelaire, C., Alsop, D. C., George, D., Pedrosa, I., Wang,Y., Michaelson, M. D., and Rofsky, N.M. (2008). Magnetic resonance imaging-measured blood flow change after antiangiogenic therapy with PTK787/ZK 222584 correlates with clinical outcome in metastatic renal cell carcinoma. Clin. Cancer Res. 14, 5548-5554.

Escudier, B., Eisen, T., Stadler, W. M., Szczylik, C., Oudard, S., Siebels, M., Negrier, S., Chevreau, C., Solska, E., Desai, A. A., Rolland, F., Demkow, T., Hutson, T. E., Gore, M., Freeman, S., Schwartz, B., Shan, M., Simantov, R., and Bukowski, R.M. (2007a). Sorafenib in advanced clear-cell renal-cell carcinoma. N. Engl. J. Med. 356, 125-134.

Escudier, B., Pluzanska, A., Koralewski, P., Ravaud, A., Bracarda, S., Szczylik, C., Chevreau, C., Filipek, M., Melichar, B., Bajetta, E., Gorbunova, V., Bay, J. O., Bodrogi, I., Jagiello-Gruszfeld, A., and Moore, N. (2007b). Bevacizumab plus interferon alfa-2a for treatment of metastatic renal cell carcinoma: a randomised double-blind phase III trial. Lancet 370, 2103-2111.

Falebita, O. A., Mancini, S., Kiely, E., and Comber, H. (2009). Rising incidence of renal cell carcinoma in Ireland. Int. Urol. Nephrol. 41, 7-12.

Ferlay, J., Autier, P., Boniol, M., Heanue, M., Colombet, M., and Boyle, P. (2007). Estimates of the cancer incidence and mortality in Europe in 2006. Ann. Oncol. $18,581-592$.

Flanigan, R. C., Mickisch, G., Sylvester, R., Tangen, C., Van Poppel, H., and Crawford, E. D. (2004). Cytoreductive nephrectomy in patients with metastatic renal cancer: a combined analysis. J. Urol. 171, 1071-1076.

Gerlinger, M., and Swanton, C. (2010). How Darwinian models inform therapeutic failure initiated by clonal heterogeneity in cancer medicine. Br. J. Cancer 103 , 1139-1143.

Hahn, O. M., Yang, C., Medved, M., Karczmar, G., Kistner E., Karrison, T., Manchen, E., Mitchell, M., Ratain, M. J., and Stadler, W. M. (2008). Dynamic contrastenhanced magnetic resonance imaging pharmacodynamic biomarker study of sorafenib in metastatic renal carcinoma. J. Clin. Oncol. 26, 4572-4578.

Hellenthal, N. J., Underwood, W., Penetrante, R., Litwin, A., Zhang, S., Wilding, G. E., Teh, B. T., and Kim, H. L. (2010). Prospective clinical trial of preoperative sunitinib in patients with renal cell carcinoma. J. Urol. 184, 859-864.

Heng, D. Y., Xie, W., Regan, M. M., Warren, M. A., Golshayan, A. R., Sahi, C., Eigl, B. J., Ruether, J. D., Cheng, T., North, S., Venner, P., Knox, J. J., Chi, K. N., Kollmannsberger, C., McDermott, D. F., Oh, W. K., Atkins, M. B., Bukowski, R. M., Rini, B. I., and Choueiri, T. K. (2009). Prognostic factors for overall survival in patients with metastatic renal cell carcinoma treated with vascular endothelial growth factortargeted agents: results from a large, multicenter study. J. Clin. Oncol. 27, 5794-5799.
Hollingsworth, J. M., Miller, D. C., Daignault, S., and Hollenbeck, B. K. (2006). Rising incidence of small renal masses: a need to reassess treatment effect. $J$. Natl. Cancer Inst. 98, 1331-1334.

Hudes, G., Carducci, M., Tomczak, P., Dutcher, J., Figlin, R., Kapoor, A., Staroslawska, E., Sosman, J., McDermott, D., Bodrogi, I., Kovacevic, Z., Lesovoy, V., Schmidt-Wolf, I. G., Barbarash, O., Gokmen, E., O’Toole, T., Lustgarten, S., Moore, L., and Motzer, R. J. (2007). Temsirolimus, interferon alfa, or both for advanced renal-cell carcinoma. N. Engl. J. Med. 356, 2271-2281.

Jemal, A., Siegel, R., Xu, J., and Ward, E. (2010). Cancer statistics, 2010. CA Cancer J. Clin. 60, 277-300.

Jonasch, E., Wood, C. G., Matin, S. F., Tu, S. M., Pagliaro, L. C., Corn, P. G., Aparicio, A., Tamboli, P., Millikan, R. E., Wang, X., Araujo, J. C., Arap, W., and Tannir, N. (2009). Phase II presurgical feasibility study of bevacizumab in untreated patients with metastatic renal cell carcinoma. J. Clin. Oncol. 27, 4076-4081.

Lee, A. J., Endesfelder, D., Rowan, A. J., Walther, A., Birkbak, N. J., Futreal, P. A., Downward, J., Szallasi, Z., Tomlinson, I. P., Howell, M., Kschischo, M., and Swanton, C. (2011). Chromosomal instability confers intrinsic multidrug resistance. Cancer Res. 71, 1858-1870.

Leibovich, B. C., Blute, M. L., Cheville, J. C., Lohse, C. M., Frank, I., Kwon, E. D., Weaver, A. L., Parker, A. S., and Zincke, H. (2003). Prediction of progression after radical nephrectomy for patients with clear cell renal cell carcinoma: a stratification tool for prospective clinical trials. Cancer 97, 1663-1671.

Margulis, V., Matin, S. F., Tannir, N., Tamboli, P., Swanson, D. A., Jonasch, E., and Wood, C. G. (2008). Surgical morbidity associated with administration of targeted molecular therapies before cytoreductive nephrectomy or resection of locally recurrent renal cell carcinoma. J. Urol. 180, 94-98.

Messing, E. M., Manola, J., Wilding, G., Propert, K., Fleischmann, J., Crawford, E. D., Pontes, J. E., Hahn, R., and Trump, D. (2003). Phase III study of interferon alfa-NL as adjuvant treatment for resectable renal cell carcinoma: an Eastern Cooperative Oncology Group/ Intergroup trial. J. Clin. Oncol. 21, 1214-1222.

Moch, H., Schraml, P., Bubendorf, L., Richter, J., Gasser, T. C., Mihatsch, M. J., and Sauter, G. (1998). Intratumoral heterogeneity of von Hippel-Lindau gene deletions in renal cell carcinoma detected by fluorescence in situ hybridization. Cancer Res. 58, 2304-2309.

Motzer, R. J., Bacik, J., Murphy, B. A., Russo, P., and Mazumdar, M. (2002). Interferon-alfa as a comparative treatment for clinical trials of new therapies against advanced renal cell carcinoma. J. Clin. Oncol. 20, 289-296.

Motzer, R. J., Bander, N. H., and Nanus, D. M. (1996). Renal-cell carcinoma. N. Engl. J. Med. 335, 865-875.

Motzer, R. J., Bukowski, R. M., Figlin, R. A., Hutson, T. E., Michaelson, M. D., Kim, S. T., Baum, C. M., and Kattan, M. W. (2008a). Prognostic nomogram for sunitinib in patients with metastatic renal cell carcinoma. Cancer 113, 1552-1558.

Motzer, R. J., Escudier, B., Oudard, S., Hutson, T. E., Porta, C., Bracarda, S., Grunwald, V., Thompson, J.A., Figlin, R. A., Hollaender, N., Urbanowitz, G., Berg, W. J., Kay, A., Lebwohl, D., and Ravaud, A. (2008b). Efficacy of everolimus in advanced renal cell carcinoma: a double-blind, randomised, placebo-controlled phase III trial. Lancet 372, 449-456. 
Motzer, R. J., Hutson, T. E., Tomczak, P., Michaelson, M. D., Bukowski, R. M., Rixe, O., Oudard, S., Negrier, S., Szczylik, C., Kim, S. T., Chen, I., Bycott, P. W., Baum, C. M., and Figlin, R.A. (2007). Sunitinib versus interferon alfa in metastatic renal-cell carcinoma. N. Engl. J. Med. 356, 115-124.

Pizzocaro, G., Piva, L., Colavita, M., Ferri, S., Artusi, R., Boracchi, P., Parmiani, G., and Marubini, E. (2001). Interferon adjuvant to radical nephrectomy in Robson stages II and III renal cell carcinoma: a multicentric randomized study. J. Clin. Oncol. 19, 425-431.

Powles, T., Kayani, I., Blank, C., Chowdhury, S., Horenblas, S., Peters, J., Shamash, J., Sarwar, N., Boletti, K., Sadev, A., O'Brien, T., Berney, D., Beltran, L., Haanen, J., and Bex, A. (2011). The safety and efficacy of sunitinib before planned nephrectomy in metastatic clear cell renal cancer. Ann. Oncol. 22, 1041-1047.

Rini, B. I., Halabi, S., Rosenberg, J. E., Stadler, W. M., Vaena, D. A., Ou, S. S., Archer, L., Atkins, J. N., Picus, J., Czaykowski, P., Dutcher, J., and Small, E. J. (2008). Bevacizumab plus interferon alfa compared with interferon alfa monotherapy in patients with metastatic renal cell carcinoma: CALGB 90206. J. Clin. Oncol. 26, 5422-5428.

Russo, P., and O’Brien, M. F. (2008). Surgical intervention in patients with metastatic renal cancer: metastasectomy and cytoreductive nephrectomy. Urol. Clin. North Am. 35: 679-86.

Shuch, B., Riggs, S. B., LaRochelle, J. C., Kabbinavar, F. F., Avakian, R., Pantuck, A. J., Patard, J. J., and Belldegrun, A. S. (2008). Neoadjuvant targeted therapy and advanced kidney cancer: observations and implications for a new treatment paradigm. BJU Int 102, 692-696.

Sternberg, C. N., Davis, I. D., Mardiak, J., Szczylik, C., Lee, E., Wagstaff, J., Barrios, C. H., Salman, P., Gladkov, O. A., Kavina, A., Zarba, J. J., Chen, M. McCann, L., Pandite, L., Roychowdhury, D. F. and Hawkins, R. E. (2010a). Pazopanib in locally advanced or metastatic renal cell carcinoma: results of a randomized phase III trial. J. Clin. Oncol. 28 , 1061-1068.

Sternberg, C. N., Szczylik, C., Lee, E., Salman, P. V., Mardiak, J., Davis, I. D., Pandite, L., Chen, M. McCann, L., Hawkins, R., San Camillo Forlanini Hospital, Rome, Italy, Military Medical Institute, Warsaw, Poland, Seoul National University College of Medicine, Seoul, Republic of Korea, Fundación Arturo Lopez Perez, Santiago, Chile, Comenius University, National Cancer Institute, Bratislava, Slovakia, Ludwig Institute for Cancer Research, Melbourne, Australia, GlaxoSmithKline, Research Triangle Park, NC, GlaxoSmithKline, Collegeville, PA, and University of Manchester, Manchester, United Kingdom. (2010b). Randomized, double-blind phase III study of pazopanib in patients with advanced/metastatic renal cell carcinoma: final overall survival results. Ann. Oncol. 21, abstr. LBA22.

Swanton, C., Larkin, J. M., Gerlinger, M., Eklund, A C., Howell, M., Stamp, G., Downward, J., Gore, M., Futreal, P. A., Escudier, B., Andre, F., Albiges, L. Beuselinck, B., Oudard, S., Hoffmann, J., Gyorffy, B. Torrance, C. J., Boehme, K. A., Volkmer, H., Toschi, L., Nicke, B., Beck, M., and Szallasi, Z. (2010). Predictive biomarker discovery through the parallel integration of clinical trial and functional genomics datasets. Genome Med. 2, 53.

Thomas, A.A., Rini, B. I., Lane, B. R., Garcia, J., Dreicer, R., Klein, E.A., Novick, A.C., and Campbell, S.C. (2009a). Response of the primary tumor to neoadjuvant sunitinib in patients with advanced renal cell carcinoma. J. Urol. 181, 518-523; discussion 523

Thomas, A. A., Rini, B. I., Stephenson, A. J., Garcia, J. A., Fergany, A., Krishnamurthi, V., Novick, A. C., Gill, I. S., Klein, E.A., Zhou, M., and Campbell, S. C. (2009b). Surgical resection of renal cell carcinoma after targeted therapy. J. Urol. 182, 881-886.

van der Veldt, A. A., Meijerink, M. R., van den Eertwegh, A. J., Bex, A., de Gast, G., Haanen, J. B., and Boven, E. (2008). Sunitinib for treatment of advanced renal cell cancer: primary tumor response. Clin. Cancer Res. 14, 2431-2436.

Received:07 November 2011; accepted: 23 November 2011; published online: 08 December 2011

Citation: Fisher R and Larkin J (2011) Renal cell cancer: what can we learn from pre-operative studies? Front. Oncol. 1:51. doi: 10.3389/fonc.2011.00051

This article was submitted to Frontiers in Genitourinary Oncology, a specialty of Frontiers in Oncology.

Copyright (c) 2011 Fisher and Larkin. This is an openaccess article distributed under the terms of the Creative Commons Attribution Non Commercial License, which permits non-commercial use, distribution, and reproduction in other forums, provided the original authors and source are credited. 